\title{
PERMINTAAN UDANG VANNAMEI (Litopenaeus vannamei ) DI KELOMPOK PEMBUDIDAYA UDANG AT-TAQWA PACIRAN LAMONGAN
}

\author{
VANNAMEI SHRIMP (Litopenaeus vannamei) DEMAND \\ IN AT-TAQWA SHRIMP CULTIVATION GROUP PACIRAN LAMONGAN
}

Wachidatus Sa'adah*, Khiqotul Milah

Fakultas Perikanan Universitas Islam Lamongan

*Email:wachidaafandi@gmail.com

(Diterima 01-07-2019; Disetujui 23-07-2019)

\begin{abstract}
ABSTRAK
Penelitian ini dilakukan dengan tujuan untuk mengetahui harga udang vannamei dan permintaan udang vannamei pada setiap musim. Penelitian ini dilaksanakan di kelompok pembudidaya udang At-Taqwa Desa Paciran Kecamatan Paciran Kabupaten Lamongan. Metode yang digunakan dalam penelitian ini adalah metode kualitatif. Hasil penelitian menunjukkan bahwa harga sangat mempengaruhi permintaan untuk pasar dalam negeri, sedangkan untuk pasar luar negeri tidak berpengaruh.
\end{abstract}

Kata kunci: Harga, Permintaan, Udang Vannamei

\section{ABSTRACT}

This research was conducted in order to know the price of shrimp vannamei and demand of shrimp vannamei at every season. This research was conducted in group of fish farmer of At-Taqwa Paciran Village, Paciran Sub-District, Lamongan Regency. The method used in this research is qualitative method. The research results showed that the price greatly affects the demand for the domestic market, while for the foreign market has no effect.

Keywords: Price, Demand, Vannamei Shrimp

\section{PENDAHULUAN}

Banyaknya permintaan udang vannamei menjadi penyebab utama para petani yang awalnya membudidayakan udang windu beralih membudidayakan udang vannamei. Di samping itu, udang vannamei mempunyai keunggulan yakni produktivitas tinggi karena kelangsungan hidupnya tinggi, mampu memanfaatkan seluruh kolom air dari dasar sampai permukaan sehingga memungkinkan dipelihara dengan kondisi padat tebar tinggi, lebih mudah dibudidayakan karena relatif lebih toleran terhadap perubahan lingkungan dan tahan terhadap penyakit, waktu pemeliharaan lebih pendek karena pertumbuhannya relatif lebih cepat (Ghufran, 2007). Keunggulan yang dimiliki oleh udang vannamei itulah yang menjadikan pembudidaya semakin mudah untuk memelihara dan merawatnya.

Di samping itu, hasil yang diperoleh sangat menguntungkan. Dibuktikan dengan semakin banyak para pembudidaya untuk meningkatkan 
PERMINTAAN UDANG VANNAMEI (Litopenaeus vannamei)

produksi agar bisa mencukupi kebutuhan pasar yang semakin meningkat. Menurut Mangampa dan Suwoyo (2010), produksi yang tinggi tidak selamanya diikuti oleh keuntungan yang tinggi. Di samping itu, penerapan kepadatan tinggi terbatas pada golongan masyarakat menengah ke atas. Produksi yang tinggi akan berdampak kepada beban limbah yang dihasilkan baik oleh sisa pakan apabila rasio konversi pakan tinggi, maupun kotoran udang.

Udang vannamei merupakan sumber pangan yang kaya protein, dengan harga yang relatif lebih murah, yang mendorong masyarakat untuk meningkatkan konsumsi udang vannamei sebagai pemenuhan gizi bagi kesehatan. Sehingga terdapat peluang besar bagi upaya peningkatan konsumsi udang vannamei di masa yang akan datang, dengan demikian akan berpengaruh terhadap permintaan yang berakibat mendorong berkembangnya kegiatan usahatani budidaya udang vannamei.

Di Provinsi Jawa Timur terhitung untuk pembudidaya udang vannamei sebanyak 21.253 petani. Apalagi sekarang banyak tambak sebagai tempat rekreasi atau tempat pemancingan (BPSK, 2016).
Hasil produksi udang vannamei di Jawa Timur hampir tiap tahunnya mengalami kenaikan. Untuk permintaan dari luar negeri pun banyak seperti Jepang, Taiwan dan negara lainnya. Sistem pembudidayaan yang digunakan pun beragam mulai dari tradisional, semi intensif, dan intensif.

Kabupaten Lamongan merupakan salah satu kabupaten yang menggunakan tambaknya sebagai tambak udang dan ikan sekaligus untuk bercocok tanam (mina padi), namun hasil yang diperoleh para petani lebih menguntungkan jika digunakan sebagai tambak udang. Udang vannamei yang dihasilkan kelompok pembudidaya udang At-Taqwa di Paciran Lamongan merupakan salah satu yang unggul di wilayah Paciran. Kelompok pembudidaya udang tersebut menggunakan sistem intensif yang berpengaruh terhadap hasil produksi dimana hasil produksinya sebanyak 40$60 / \mathrm{kg}$.

Harga udang vannamei setiap tahunnya mengalami kenaikan sebesar 10\%. Harga udang vannamei setiap musim berbeda-beda, semakin mendekati musim jarang semakin tinggi harganya, dan itu akan mempengaruhi pada permintaan konsumen. Permintaan akan udang vannamei pada kelompok 
pembudidaya udang ini banyak yang berasal dari luar negeri yaitu Jepang, Taiwan, dan Amerika, sedangkan untuk permintaan dari dalam negeri yaitu dari industri pengolahan. Permintaan yang berasal dari luar negeri tidak membatasi jumlah permintaannya, berapapun jumlah produksi yang didapatkan oleh kelompok pembudidaya udang At-Taqwa Paciran akan dibeli semua tanpa mempertimbangkan harga. Sedangkan pada pembeli dalam negeri masih mempertimbangkan harga.

Berdasar latar belakang di atas, maka tujuan dari penelitian adalah untuk mengetahui berapa jumlah permintaan udang vannamei di kelompok pembudidaya At-Taqwa Paciran Lamongan dari dalam negeri dan luar negeri.

\section{METODE PENELITIAN}

Metode yang digunakan dalam penelitian ini adalah metode kualitatif. Penelitian ini dilaksanakan di kelompok pembudidaya udang At-Taqwa Paciran Lamongan, dasar pemilihan kelompok tersebut karena merupakan salah satu kelompok pembudidaya udang yang unggul di wilayah Paciran Lamongan.

Teknik pengumpulan data yang digunakan terdiri atas dua macam, yaitu data primer dan data sekunder. Data primer diperoleh secara langsung dengan melakukan observasi, wawancara dan partisipasi aktif. Sedangkan data sekunder diperoleh melalui studi literatur, discovery learning melalui internet, dan lain-lain (Wachidatus, 2018).

\section{HASIL DAN PEMBAHASAN}

\section{a. Profil Usaha}

Desa Paciran adalah desa yang paling luas arealnya yang ada di Kecamatan Paciran. Kelompok pembudidaya udang At-Taqwa merupakan kelompok pemudidaya udang vannamei yang ada di Desa Paciran. Berdasarkan letak strategi Desa Paciran terletak di antara beberapa desa. Untuk lebih jelasnya dapat diketahui sebagai berikut.

Nama Desa : Desa Paciran

Batas Selatan : Desa Sumuran

Batas Barat : Desa Wates

Batas Timur : Desa Jetak

Pada awalnya tambak ini didirikan pada tahun 1990, dan komoditi yang pertama kali ditebar adalah udang windu. Namun mudahnya penyakit yang menyerang komoditi tersebut sehingga pada tahun 2010 mulai beralih ke udang vannamei yang mempunyai kemudahan dalam perawatan dan tidak mudah 
PERMINTAAN UDANG VANNAMEI (Litopenaeus vannamei)

diserang panyakit, di samping itu juga mempunyai nilai ekonomis yang tinggi karena harga jualnya bagus.

Tambak yang diusahakan oleh kelompok pembudidaya ini adalah tambak intensif, dimana terdapat sarana kincir, sumber air dari mata air, dan serangkaian pakan buatan untuk udang.

Untuk menghasilkan komoditas vaname yang unggul, maka proses pemeliharaan harus memperhatikan aspek internal yang meliputi asal dan kualitas benih; serta faktor eksternal mencakup kualitas air budidaya, pemberian pakan, teknologi yang digunakan, serta pengendalian hama dan penyakit (Haliman dan Adijaya, 2005).

Keberhasilan budidaya udang vaname sangat ditentukan oleh pemilihan lokasi. Aspek yang perlu diperhatikan adalah aspek perairan. Suatu lahan tambak layak digunakan jika memenuhi syarat-syarat tertentu agar kehidupan udang vaname tidak terganggu sehingga produksi tambak memberikan hasil yang memuaskan. Untuk meyakinkan kondisi lingkungan dapat mendukung kegiatan budidaya udang vaname, maka perlu dilakukan kajian kesesuaian lahan berdasarkan syarat-syarat yang mempengaruhi kehidupan udang, keamanan dan kelangsungan budidaya (Awanis dkk, 2017).

\section{b. Produksi Udang Vannamei}

Pada setiap tambak yang diusahakan memperoleh hasil produksi yang berbeda-beda meskipun jumlah tebar dan perawatannya sama karena didasarkan atas ukuran tambak. Hasil produksi itu bisa naik atau turun tergantung pada cuaca. Pada saat musim jumlah produksi per tambak akan naik sekitar 13\% dibandingkan pada saat tidak pada musimnya.

Pada setiap siklus jumlah total yang diperoleh oleh kelompok pembudidaya udang vannamei dari ukuran 40-60/kg pada keseluruhan tambak adalah sebagai berikut: pada saat musim diperoleh $48.000 \mathrm{~kg}$, saat kondisi sedang dan jarang hasil produksi akan turun, pada kondisi sedang diperoleh $42.000 \mathrm{~kg}$, sedangkan pada kondisi jarang diperoleh $35.000 \mathrm{~kg}$.

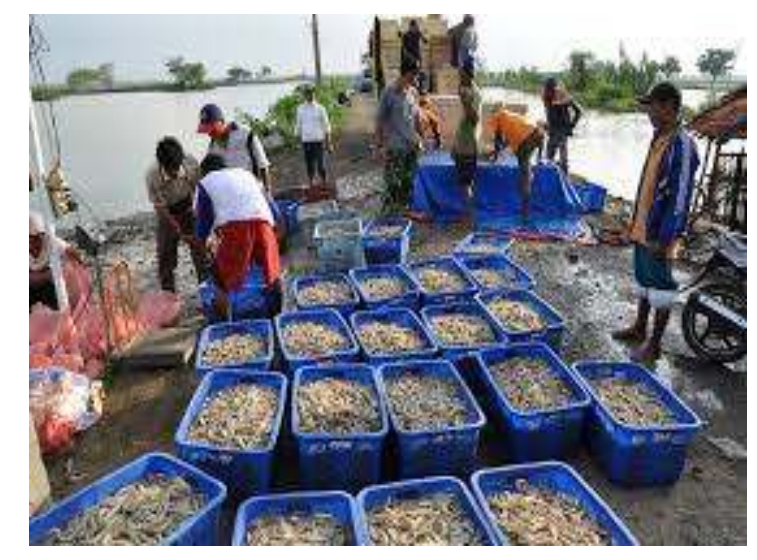

Gambar 1. Produksi Udang Vannamei 
Hasil produksi udang vannamei per tahun di kelompok pembudidaya udang vannamei Desa Paciran Kecamatan Paciran Kabupaten Lamongan dapat dilihat pada Tabel 1.

Tabel 1. Data Produksi Udang Vannamei Tahun 2018

\begin{tabular}{lcc}
\hline Kondisi & Ukuran & $\begin{array}{c}\text { Jumlah Produksi } \\
\text { (Kg) }\end{array}$ \\
\hline Musim & 40 & 9.000 \\
& 50 & 26.000 \\
Sedang & 60 & 13.000 \\
& 40 & 20.000 \\
\multirow{4}{*}{ Jarang } & 50 & 9.000 \\
& 40 & 13.000 \\
& 50 & 18.000 \\
& 60 & 11.000 \\
\hline
\end{tabular}

Sumber: Data Primer, 2018

\section{c. Harga Udang Vannamei}

Udang vannamei (Litopenaeus vannamei) adalah jenis udang dari Amerika Selatan yang mulai dibudidayakan di Indonesia sejak akhir dekade 90-an. Udang vannamei memiliki sifat yang lebih responsif terhadap pakan dengan kadar protein $25-30 \%$ (lebih rendah dari udang windu). Udang vannamei dibudidayakan untuk menggantikan udang windu (Penaeus monodon) yang sudah sulit dibudidayakan karena serangan virus Whitespot.

Menurut Zainal (2017), harga produksi perikanan cenderung tidak stabil (berubah-ubah) dibandingkan hargaharga komoditas lainnya, hal ini

disebabkan adanya perubahan yang sulit untuk diramalkan seperti kondisi alam, cuaca, dan lain-lain.

Harga memiliki peranan penting yaitu untuk menyampaikan informasi ke produsen terhadap barang yang diinginkan dan dibutuhkan konsumen, dan juga untuk menginformasikan kepada konsumen tentang berbagai kondisi produksi.

Harga pada udang vannamei akan berubah-ubah seiring dengan perubahan musim. Jika pada saat musim maka harga akan turun, dan jika tidak pada saat musim maka harga akan naik; di samping itu juga dipengaruhi oleh kualitas dan ukuran dari udang itu sendiri.

Harga yang ditawarkan untuk konsumen dalam negeri dan luar negeri akan berbeda, hal ini disebabkan karena adanya biaya pengemasan, transportasi, bea cukai dan biaya tambahan lainnya. Untuk mengetahui harga udang vannamei dapat dilihat pada Tabel 2 .

Tabel 2. Harga Udang Vannamei Tahun 2018

\begin{tabular}{lcrr}
\hline Kondisi & Ukuran & \multicolumn{2}{c}{ Harga $(\mathrm{Rp})$} \\
\cline { 3 - 4 } & & $\begin{array}{c}\text { Dalam } \\
\text { Negeri }\end{array}$ & $\begin{array}{c}\text { Luar } \\
\text { Negeri }\end{array}$ \\
\hline Musim & 40 & 75.000 & 75.000 \\
& 50 & 55.000 & 60.000 \\
\multirow{4}{*}{ Sedang } & 60 & 45.000 & 45.000 \\
& 40 & 85.000 & 90.000 \\
& 50 & 70.000 & 75.000 \\
Jarang & 60 & 55.000 & 60.000 \\
& 40 & 120.000 & 125.000 \\
& 50 & 105.000 & 120.000 \\
& 60 & 85.000 & 90.000 \\
\hline Sumber: Data Primer 2018 & &
\end{tabular}


PERMINTAAN UDANG VANNAMEI (Litopenaeus vannamei)

\section{d. Permintaan Udang Vannamei}

Permintaan (demand) adalah jumlah dari suatu barang yang mau dan dapat dibeli oleh konsumen pada berbagai kemungkinan harga, dalam jangka waktu tertentu, dengan anggapan hal-hal yang lain tetap sama (cateris paribus) (Rita, 2010). Permintaan merupakan bagian terpenting dari suatu produksi. Permintaan akan mempengaruhi jumlah produk yang akan dihasilkan.

Adapun permintaaan udang vannamei dari dalam negeri didasarkan atas kesepakatan bersama antara kedua belah pihak yaitu pihak kelompok pembudidaya At-Taqwa dengan konsumen lokal mengenai jumlah dan harganya. Sedangkan permintaan udang vannamei untuk luar negeri didasarkan atas kondisi musim, kualitas, dan ketersediaan produk yang bisa terpenuhi secara terus-menerus. Jika saat kondisi musim, permintaaan dari luar negeri akan berkurang dikarenakan beberapa negara tetangga juga mengalami panen raya.

Beberapa negara yang menjadi tujuan memasarkan produk ini adalah Taiwan, Amerika Serikat, dan Jepang. Negara-negara tersebut akan membeli berapapun jumlah udang vannamei yang diproduksi pada setiap panen, misalnya dalam panen jumlah produksi udang vannamei di kelompok pembudidaya udang At-Taqwa menghasilkan 13.000 $\mathrm{kg}$. Kemudian ada permintaan dari dalam negeri sebanyak $4.000 \mathrm{~kg}$, maka sisa dari hasil panen sebesar $9.000 \mathrm{~kg}$ akan dijual ke negara tujuan (Taiwan, Amerika Serikat, dan Jepang). Terkadang kelompok pembudidaya ini lebih memperioritaskan permintaan dari luar negeri dibandingkan permintaan dalam negeri.

Jumlah permintaan dari luar negeri lebih banyak dari pada di dalam negeri. Alasan konsumen dari luar negeri meminta udang dari kelompok ini karena kualitas dan kuantitas yang mereka inginkan sesuai. Sedangkan konsumen dari dalam negeri ini meminta karena sudah adanya perjanjian yang telah disepakati oleh kedua belah pihak.

Untuk mengetahui permintaan udang vannamei di kelompok pembudidaya udang At-Taqwa Paciran dapat dilihat pada Tabel 3 dan 4.

Tabel 3. Permintaan Udang Vannamei di Dalam Negeri Tahun 2018

\begin{tabular}{cccc}
\hline Kondisi & Ukuran & \multicolumn{1}{c}{$\begin{array}{c}\text { Harga } \\
(\mathrm{Rp})\end{array}$} & $\begin{array}{c}\text { Permintaan } \\
(\mathrm{Kg})\end{array}$ \\
\hline Musim & 40 & 75.000 & 6.000 \\
& 50 & 55.000 & 6.000 \\
Sedang & 60 & 45.000 & 6.000 \\
& 40 & 85.000 & 7.000 \\
& 50 & 70.000 & 3.000 \\
Jarang & 60 & 55.000 & 2.000 \\
& 40 & 120.000 & 3.000 \\
& 50 & 105.000 & 2.000 \\
& 60 & 85.000 & 1.000 \\
\hline
\end{tabular}

Sumber: Data Primer, 2018 
Tabel 4. Permintaan Udang Vannamei di Luar Negeri Tahun 2018

\begin{tabular}{lcrr}
\hline Kondisi & Ukuran & $\begin{array}{c}\text { Harga } \\
(\mathrm{Rp})\end{array}$ & $\begin{array}{c}\text { Permintaa } \\
\mathrm{n}(\mathrm{Kg})\end{array}$ \\
\hline Musim & 40 & 80.000 & 3.000 \\
& 50 & 60.000 & 20.000 \\
Sedang & 60 & 45.000 & 9.000 \\
& 40 & 90.000 & 12.000 \\
Jarang & 50 & 75.000 & 10.000 \\
& 60 & 60.000 & 7.000 \\
& 40 & 125.000 & 15.000 \\
& 50 & 110.000 & 9.000 \\
& 60 & 90.000 & 5.000
\end{tabular}

Sumber: Data Primer, 2018

Dari data pada Tabel 3 dan 4 dapat disimpulkan bahwa harga pada udang vannamei yang ada di kelompok ini tidak mempengaruhi permintaan, baik itu dilihat dari segi ekonomis atau psikologis.

Permintaan udang vannamei di kelompok pembudidaya udang At-Taqwa Paciran pada saat panen raya mengalami penurunan permintaan karena negara tetangga juga dalam posisi panen raya. Posisi saat inilah yang akan mempengaruhi harga pada udang vannamei sehingga mengalami penurunan. Udang akan dijual di bawah harga normal. Sebaliknya, harga akan mengalami kenaikan pada saat kondisi jarang, dan harga udang akan mencapai posisi yang tertinggi.

\section{KESIMPULAN DAN SARAN}

Pengaruh harga terhadap permintaan di kelompok pembudidaya udang At-Taqwa Paciran tidak begitu berpengaruh besar, karena adanya permintaan dari luar negeri yang selalu membeli berapapun jumlah udang yang tersedia. Pada kelompok ini jumlah produksi pada kondisi saat musim bisa mencapai $48.000 \mathrm{~kg}$, sedangkan pada musim sedang mencapai $42.000 \mathrm{~kg}$ dan pada musim jarang mencapai $35.000 \mathrm{~kg}$,

Adapun harga yang pernah didapatkan kelompok ini pada kondisi saat musim dengan ukuran 40/kg harga dalam negeri sebesar Rp 75.000, sedangkan harga luar negeri sebesar Rp. 75.000, untuk ukuran 50/kg harga dalam negeri sebesar $\mathrm{Rp}$ 60.000, dan harga untuk luar negeri sebesar Rp 60.000, untuk 60/kg harga dalam negeri sebesar Rp 45.000, dan harga untuk luar negeri sebesar Rp 45.000.

Adapun untuk kondisi musim sedang dengan ukuran 40/kg harga dalam negeri sebesar Rp 85.000, sedangkan harga untuk luar negeri sebesar Rp 90.000, untuk ukuran 50/kg harga dalam negeri sebesar Rp 70.000, dan harga untuk luar negeri sebesar Rp 75,000, untuk ukuran 60/kg harga dalam negeri sebesar Rp 55.000, dan harga untuk luar negeri sebesar $\operatorname{Rp} 60.000$.

Harga pada kondisi musim jarang ukuran 40/kg harga dalam negeri sebesar 
PERMINTAAN UDANG VANNAMEI (Litopenaeus vannamei)

Rp 120.000 dan harga untuk luar negeri sebesar Rp 125.000, untuk ukuran 50/kg harga dalam negeri sebesar Rp 105.000, harga untuk luar negeri sebesar $\mathrm{Rp}$ 110.000 untuk ukuran 60/kg dengan harga sebesar Rp 85.000, dan harga untuk luar negeri sebesar Rp 90.000.

Jumlah permintaan dalam negeri pada kondisi saat musim sebanyak 4.000 $\mathrm{kg}$ untuk ukuran 40/kg, dan $9.000 \mathrm{~kg}$ untuk luar negeri, untuk ukuran $50 / \mathrm{kg}$ permintaan dari dalam negeri sebanyak $6.000 \mathrm{~kg}$ dan $20.000 \mathrm{~kg}$ untuk luar negeri, pada ukuran $60 / \mathrm{kg}$ jumlah yang diminta $6.000 \mathrm{~kg}$ dan $3.000 \mathrm{~kg}$ untuk luar negeri.

Jumlah permintaan dalam negeri pada kondisi musim sedang untuk ukuran 40/kg sebanyak $7.000 \mathrm{~kg}$ dan $12.000 \mathrm{~kg}$ untuk luar negeri, pada ukuran $50 / \mathrm{kg}$ sebanyak $3.000 \mathrm{~kg}$ untuk dalam negeri dan $10.000 \mathrm{~kg}$ untuk luar negeri, pada ukuran 60/kg jumlah permintaan yang diminta dari dalam negeri sebanyak 2.000 $\mathrm{kg}$ dan $7.000 \mathrm{~kg}$ untuk luar negeri.

Jumlah permintaan dalam negeri pada kondisi musim jarang sebanyak $3.000 \mathrm{~kg}$ dan $15.000 \mathrm{~kg}$ dengan ukuran 40/kg, sedangkan pada ukuran 50/kg jumlah yang diminta dari dalam negeri sebanyak $2.000 \mathrm{~kg}$ dan $9.000 \mathrm{~kg}$ untuk luar negeri, dan pada ukuran 60/kg jumlah yang diminta dari dalam negeri sebanyak $1.000 \mathrm{~kg}$ dan $5.000 \mathrm{~kg}$ untuk luar negeri.

Faktor yang mempengaruhi jumlah permintaan dari dalam negeri itu adalah harga. Jika harga naik maka permintaan akan berkurang, dan sebaliknya seperti halnya hukum permintaan.

Namun berbeda dengan permintaan luar negeri, faktor yang mempengaruhinya adalah kualitas dan kontinuitas ketersediaan komoditi secara terusmenerus, berapapun jumlah dan harga yang ditawarkan oleh kelompok pembudidaya tidak menjadi persoalan bagi konsumen luar negeri asal kualitasnya baik. Hal ini yang memotivasi kelompok pembudidaya untuk meningkatkan produksi dan kualitas udang vannamei dengan cara memperhatikan proses persiapan, pemeliharaan hingga panen yang baik.

\section{UCAPAN TERIMA KASIH}

Ucapan terima kasih disampaikan kepada semua pihak yang telah berperan dalam kegiatan penelitian, khususnya pada kelompok pembudidaya udang vannamei At-Taqwa di Paciran Lamongan, sehingga kegiatan penelitian ini dapat berjalan dengan lancar. 


\section{DAFTAR PUSTAKA}

Abidin, Z dkk. 2017. Pemasaran Hasil Perikanan. UB Press, Malang.

Awanis, A.A., Prayitno, S.B. dan Herawati, V.E. 2017. Kajian Kesesuaian Lahan Tambak Udang Vaname dengan Menggunakan Sistem Informasi Geografis di Desa Wonorejo, Kecamatan Kaliwungu, Kendal, Jawa Tengah. Buletin Oseanografi Marina 6(2):102-109.

BSPK. 2016. Pembudidaya Ikan di Lamongan. Badan Statistika Perikanan dan Kelautan Jawa Timur.

Haliman, R.W. dan D. Adijaya. 2005. Udang Vannamei, Pembudidayaan dan Prospek Pasar Udang Putih yang Tahan Penyakit. Jakarta: Penebar Swadaya.
Hanafie, R. 2010. Pengantar Ekonomi Pertanian. Yogyakarta: Andi Offset.

Mangampa, M. Suwoyo, H.S. 2010. Budidaya Udang Vaname (Litopenaeus vannamei) Teknologi Intensif Menggunakan Benih Tokolan. J. Ris. Akuakultur 5(3): 351-361.

M, Ghufran, H dan Kordi, K. 2007. Pemeliharaan Udang Vannmae. Surabaya: Indah.

Sa'adah, W. 2018. Upaya Peningkatan Pemasaran Benur Udang Vannamei (Litopenaeus Vannamei) di PT. Artha Maulana Agung (AMA) Desa Pecaron, Kecamatan Bungatan Kabupaten Situbondo, Mimbar Agribisnis: Jurnal Pemikiran Masyarakat Ilmiah Berwawasan Agribisnis, 4(1): 8497. 